\title{
Genetic Diversity for Yield Components, Physical and Biochemical Quality Parameters in Colored Rice (Oryza sativa L.)
}

\author{
P. Sri Devi ${ }^{1 *}$, B. Krishna Veni ${ }^{1}$ and D. Sandeep Raja ${ }^{2}$ \\ ${ }^{1}$ Agricultural College, ${ }^{2}$ AICRP on PHET, Bapatla 522101, Andhra Pradesh, India \\ *Corresponding author
}

\section{A B S T R A C T}

\section{Keywords}

Colored rice, Quality parameters, Clusters, D2 analysis

\section{Article Info}

Accepted:

04 October 2019

Available Online:

10 November 2019
An investigation was carried out with twenty six colored rice (Oryza sativa L.) genotypes to study the genetic divergence using $\mathrm{D}^{2}$ statistics. Based on 26 yield and quality traits, these genotypes were grouped into six clusters. Among these six clusters, cluster I possessed more number of genotypes (11) followed by cluster II with 8 genotypes and cluster III with 3 genotypes. Cluster II recorded maximum intra cluster distance, while highest inter cluster distance was observed between cluster $\mathrm{V}$ and cluster VI. Cluster II had highest mean value for grain yield/plant whereas the genotypes grouped in cluster III exhibited highest mean value for panicle length, number of filled grains/panicle and total number of grains/panicle. Cluster V was characterized by highest mean value for ear bearing tillers/plant and test weight among yield components and total starch content, $\mathrm{Zn}$ content \& slowly digestible starch among quality parameters. Cluster VI manifested highest mean value for most of physic-chemical and biochemical quality traits studied viz., water uptake, volume expansion ratio, length/breadth ratio, total phenol content, total antioxidant activity, flavonoid content and $\mathrm{Fe}$ content. Hybridization among genotypes from cluster $\mathrm{V}$ and VI, cluster I and VI followed by cluster II and VI which had maximum inter cluster distances may result in maximum genetic improvement of yield and desirable quality traits of colored rice.

\section{Introduction}

As the consumers become more health conscious and aware of the benefits of functional foods, diets containing bio-active compounds (secondary metabolites) such as antioxidants have received greater attention. Pigmented rice has been categorized as one of the potent functional foods since it contains high amounts of phenolic compounds (Yawadio et al., 2007). Owing to several health promoting impacts associated with anthocyanins, such as anti-oxidative, antiinflammatory and anti-carcinogenic effects, coloured rice is considered as a functional food and food ingredient in many Asian 
countries. The success of any plant breeding programme largely depends on the existence of diversity among the genotypes (Allard, 1960). This helps in the choice of parents for hybridization in yield improvement programmes. Hence, estimation of genetic diversity for yield components and quality parameters among genotypes is important for planning the future hybridization programme. Mahalanobis' $\mathrm{D}^{2}$ statistic has proved to be powerful technique for estimating genetic divergence among the genotypes. Hence, the present investigation was carried out to ascertain the value and magnitude of genetic diversity between 26 colored rice genotypes.

\section{Materials and Methods}

Twenty six rice genotypes comprising of varieties developed at Agricultural Research Station, Bapatla and varieties received from ARS Pattambi, Kerala (Table 1) were used in the present study. Among the 26 genotypes seven had light brown pericarp color and nine genotypes possess red pericarp color. The remaining ten genotypes had black pericarp color. BPT 5204, a popular high yielding genotype with excellent cooking quality traits is used as check variety in the present study. The present investigation was carried out during kharif, 2017 at Agricultural College Farm, Bapatla. These genotypes were evaluated in randomized block design with three replications under direct sowing by following manual dibbling method. Each genotype was sown in 10 rows of $3 \mathrm{~m}$ length. Observations were recorded on ten plants selected at random per genotype per replication for 9 yield components and 6 physico-chemical quality traits viz., days to $50 \%$ flowering, panicle length $(\mathrm{cm})$, plant height $(\mathrm{cm})$, ear bearing tillers per plant, grain yield per plant $(\mathrm{g})$, test weight $(\mathrm{g})$, number of filled grains per panicle, total number of grains per panicle, fertility (\%), solid loss, water uptake, volume expansion ratio, alkali spreading value, length/breadth ratio and amylose content (\%). However, days to $50 \%$ flowering and test weight $(\mathrm{g})$ were recorded on plot basis along with quality parameters. The polished rice was used for estimation of solid loss, water uptake, volume expansion ratio, length/breadth ratio, alkali spreading value and amylose content by following standard procedures delineated by Sidhu et al., (1975), Directorate of Rice Research (2006), Little et al., (1958) and Juliano (1971). Each sample per genotype per replication was dehusked and utilized for estimation of 11 nutritional and bio-chemical quality parameters viz., total starch content (\%), protein Content (\%), Zn content (ppm), iron content (ppm), total phenol content $(\mathrm{mg} / 100$ $\mathrm{g}$ ), total antioxidant activity (mg AAE/100 g), total flavonoid content $(\mathrm{mg} / 100 \mathrm{~g})$, glycemic index (\%), slowly digestible starch (\%), rapidly digestible starch $(\%)$ and resistant starch $(\%)$ by following standard procedures delineated by Hodge, J.E and Hofrieter (1962), Lowry et al., 1951, DRR (2006), Malik C.P and Singh M.B.(1980), Pathirana et al., (2005), Swain et al., (1959), Goni et al., (1997) Englyst et al., (1999), Goni et al., (1996) respectively. Genetic divergence analysis was done following the $\mathrm{D}^{2}$ statistics proposed by Mahalanobis (1936).

\section{Results and Discussion}

The analysis of variance showed significant differences for all characters studied except for solid loss, volume expansion ratio and length/breadth ratio indicating wide variability among the genotypes under study. The twenty six genotypes were grouped in to six different clusters based on the relative magnitude of $\mathrm{D}^{2}$ values. Among six clusters, cluster I had maximum number of genotypes (11) followed by cluster II with 8 genotypes and cluster III with 3 genotypes (Table 2). The clusters V and VI are solitary clusters with nil intracluster $\mathrm{D}^{2}$ values. The distribution of 
genotypes in cluster I indicated that different colored genotypes from different geographical regions grouped in single cluster. Ramesh et al., (2007) Dushyantha (2008) and Eswar et al., (2017) also reported similar findings. Character wise percent contribution towards genetic divergence by all the 26 characters is presented in Table 3. In $\mathrm{D}^{2}$ analysis, resistant starch $(71.38 \%)$ contributed maximum genetic divergence followed by slowly digestible starch (18.15\%) and flavonoid content (4.0\%).

These results of the present study indicate that the variation observed between different colored genotypes is mainly due to biochemical quality parameters

The magnitude of intra cluster distance measures the extent of genetic diversity between the genotypes of same cluster while the inter cluster distance measures the extent of genetic diversity between two clusters. The maximum inter cluster distance was observed between cluster V and cluster VI (826253.6) followed by cluster I and cluster VI (654680.6) (Table 4). Highest intra cluster distance was observed in cluster II followed by cluster III and cluster I. The maximum intra cluster distance observed in cluster II (14919.71) suggest the presence of wide genetic diversity among the genotypes viz., BPT 3111, BPT 3138, BPT 3143, BPT 3143, BPT 3137, BPT 3136, BPT 3142, BPT 3145 grouped in this cluster. The genotypes of this cluster include both black and red pericarp colored genotypes. Cluster distances showed wide range among the genotypes studied indicating that the variation may be due to the diverse material included in the present study. For a successful breeding programme, selection of genetically diverse parents is an important pre-requisite to get the desirable recombinants. Similar findings were previously reported by Sandhya et al., (2007), Parimalan et al., (2008) and Eswar et al., (2017).
The genotypes grouped in cluster I manifested highest mean value for days to $50 \%$ flowering while the genotypes of cluster II had highest mean value for grain yield/plant (Table 5). Cluster III was characterized by highest mean value for panicle length, number of filled grains/panicle, total number of grains/panicle and fertility (\%) among yield components.

Among quality parameters, the genotypes of cluster III recorded high protein content and resistant starch suggesting that the genotypes grouped in this cluster are nutritionally superior with high protein content and resistant starch. Patindol et al., (2010) and Odenigbo et al., (2013) reported that high RS content will manifest lower GI and hence, the genotypes grouped in this cluster may be suitable for diabetic diet as they possess more resistant starch. Cluster IV had highest mean value for plant height while cluster $\mathrm{V}$ was characterized by highest mean value for ear bearing tillers/plant and test weight among yield components and total starch content, $\mathrm{Zn}$ content \& slowly digestible starch among quality parameters. Cluster VI manifested highest mean value for most of physicchemical and biochemical quality traits studied viz., water uptake, volume expansion ratio, length/breadth ratio, total phenol content, total antioxidant activity, flavonoid content and $\mathrm{Fe}$ content suggesting that this genotype had good cooking quality with more cooked rice volume. The genotype BPT 3140 also recorded high Fe content and anti-oxidant activity also hence, may be used in hybridization programme to get segregants possessing desirable nutritional traits.

Choice of particular cluster and selection of particular genotype from selected cluster are the two important points to be considered before initiating the crossing programme. The hybrids between varieties of diverse clusters will express high heterosis and give more useful segregants (Table 6). 
Table.1 Details of the pedigree and pericarp colour of the genotypes used in the present study

\begin{tabular}{|c|c|c|c|}
\hline S. No. & Designation & Cross combination & $\begin{array}{l}\text { Pericarp } \\
\text { colour }\end{array}$ \\
\hline 1. & BPT 5204 & GEB 24/TN1/ Mahsuri & \multirow{7}{*}{$\begin{array}{l}\text { Light brown } \\
\text { pericarp }\end{array}$} \\
\hline 2. & BPT 2270 & BPT 5204/CRMR 1523 & \\
\hline 3. & BPT 2295 & BPT 1768/ NLR 33641 & \\
\hline 4. & BPT 2595 & Mutant of BPT 2270 & \\
\hline 5. & BPT 2782 & NLR 145/ MTU 2077 & \\
\hline 6. & BPT 2660 & BPT 1768/ NLR 145 & \\
\hline 7. & BPT 2776 & BPT 2231/ NLR 145 & \\
\hline 8. & Matta Triveni & Re-selection from Triveni & \multirow[t]{8}{*}{ Red pericarp } \\
\hline 9. & Annapurna & PTB 10/TN 1 & \\
\hline 10. & Aathira & BR 51-46-1/C.2332-2-2 & \\
\hline 11. & Harsha & M 210/ PTB 28 & \\
\hline 12. & Jyothi & PTB 10/ IR 8 & \\
\hline 13. & Samyuktha & Pureline selection from culture C3-2 & \\
\hline 14. & BPT 3111 & Swarna/ IRGC 18195// MTU 1081 & \\
\hline 15. & BPT 2858 & RP Bio 226 1/1RGC 48493 & \\
\hline 16. & BPT 3139 & Cult. $01120305 /$ cult. $0910025-7$ & \multirow{11}{*}{$\begin{array}{c}\text { Black } \\
\text { pericarp }\end{array}$} \\
\hline 17. & BPT 3137 & RP Bio 226*1/ 1RGC 48493 & \\
\hline 18. & BPT 3145 & RP Bio 226/ IRGC26940// MTU 1081 & \\
\hline 19. & BPT 3138 & RP Bio $226 * 1 / 1$ RGC 18195 & \\
\hline 20. & BPT 3136 & RP Bio 226*1/1RGC 18195 & \\
\hline 21. & BPT 3140 & Swarna/1RGC 18195 /MTU 1081 & \\
\hline 22. & BPT 3141 & RP Bio 226*1/ 1RGC 30938 & \\
\hline 23. & BPT 3142 & RP Bio 226/ 1RGC 26940// MTU 1081 & \\
\hline 24. & BPT 3143 & RP Bio 226*1/ RGC 48493 & \\
\hline 25. & BPT 2848 & RP Bio 226*1/1RGC 48493 & \\
\hline 26. & BPT 3144 & RP Bio $226^{*} 1 / 1$ RGC 48493 & \\
\hline
\end{tabular}

Table.2 Clustering pattern of colored rice (Oryza sativa L.) genotypes by Tocher's method

\begin{tabular}{|c|c|c|}
\hline Cluster No. & No. of Genotypes & Designation of the Genotypes \\
\hline I & 11 & $\begin{array}{c}\text { BPT 2295, BPT 2782, BPT 2270, BPT 5204, BPT 2595, } \\
\text { Samyuktha, Annapurna, Harsha, BPT 2660, BPT 2776, BPT } \\
3139\end{array}$ \\
\hline II & 8 & $\begin{array}{c}\text { BPT 3111, BPT 3138, BPT 3143, BPT 3143, BPT 3137, BPT } \\
\text { 3136, BPT 3142, BPT } 3145\end{array}$ \\
\hline III & 3 & BPT 3141, BPT 2848, BPT 2858 \\
\hline IV & 2 & Jyothi, BPT 3144 , \\
\hline $\mathbf{V}$ & 1 & Aathira \\
\hline VI & 1 & BPT 3140 \\
\hline
\end{tabular}


Table.3 Contribution of different characters towards genetic divergence among colored rice (Oryza sativa L.) genotypes

\begin{tabular}{|c|c|}
\hline Character & Percent contribution towards divergence \\
\hline Days to $50 \%$ flowering & 0.01 \\
\hline Panicle length $(\mathrm{cm})$ & 0.01 \\
\hline Plant height (cm) & 0.01 \\
\hline Ear bearing tillers per plant & 0.01 \\
\hline Grain Yield per plant (g) & 0.01 \\
\hline Test Weight (g) & 0.01 \\
\hline Number of filled grains per panicle & 0.01 \\
\hline Total number of grains per panicle & 0.01 \\
\hline Fertility \% & 0.01 \\
\hline Solid Loss & 0.01 \\
\hline Water Uptake & 1.85 \\
\hline Volume Expansion Ratio & 0.01 \\
\hline Alkali Spreading Value & 0.01 \\
\hline Length/Breadth ratio & 0.01 \\
\hline Amylose Content (\%) & 0.01 \\
\hline Protein Content (\%) & 0.01 \\
\hline Total Starch Content (\%) & 0.31 \\
\hline Total Phenol Content (mg/100g) & 0.62 \\
\hline Total antioxidant Activity (mg AAE/100g) & 0.31 \\
\hline Flavonoid content $(\mathrm{mg} / \mathbf{1 0 0 g})$ & 4.00 \\
\hline Zn content (ppm) & 1.54 \\
\hline Iron content (ppm) & 0.01 \\
\hline Glycemic Index & 0.31 \\
\hline Slowly Digestible Starch (\%) & 18.15 \\
\hline Rapidly Digestible Starch (\%) & 1.54 \\
\hline Resistant Starch (\%) & 71.38 \\
\hline
\end{tabular}

Table.4 Average intra and inter cluster $\mathrm{D}^{2}$ values among six clusters in 26 colored rice (Oryza sativa L.) genotypes

\begin{tabular}{|c|c|c|c|c|c|c|}
\hline Cluster No. & Cluster I & Cluster II & Cluster III & Cluster IV & Cluster V & Cluster VI \\
\hline Cluster I & $\mathbf{9 4 5 7 . 7 4}$ & 44831.25 & 332166.00 & 151487.60 & 26774.73 & 654680.60 \\
\hline Cluster II & & $\mathbf{1 4 9 1 9 . 7 1}$ & 174391.30 & 51429.46 & 81783.85 & 412625.40 \\
\hline Cluster III & & & $\mathbf{1 2 9 3 7 . 8 4}$ & 45563.13 & 46392.50 & 64390.78 \\
\hline Cluster IV & & & & $\mathbf{6 1 5 1 . 0 4}$ & 233436.80 & 186465.70 \\
\hline Cluster V & & & & & $\mathbf{0 . 0 0}$ & 826253.60 \\
\hline Cluster VI & & & & & & $\mathbf{0 . 0 0}$ \\
\hline
\end{tabular}

Diagonal bold values indicate intra cluster distances 
Table.5 Mean values of six clusters for yield components and quality parameters in colored rice (Oryza sativa L.) genotypes

\begin{tabular}{|c|c|c|c|c|c|c|c|c|c|c|c|c|c|c|c|}
\hline $\begin{array}{l}\text { Character/ } \\
\text { cluster No. }\end{array}$ & $\begin{array}{c}\text { Days } \\
\text { to 50\% } \\
\text { Floweri } \\
\text { ng }\end{array}$ & $\begin{array}{c}\text { Panicle } \\
\text { Length } \\
\text { (cm) }\end{array}$ & $\begin{array}{c}\text { Plant } \\
\text { Height } \\
\text { (cm) }\end{array}$ & $\begin{array}{c}\text { Ear } \\
\text { Bearing } \\
\text { Tillers/ } \\
\text { Plant }\end{array}$ & $\begin{array}{c}\text { Grain } \\
\text { Yield/ } \\
\text { Plant (g) }\end{array}$ & $\begin{array}{c}\text { Test } \\
\text { Weight } \\
\text { (g) }\end{array}$ & $\begin{array}{l}\text { No.of } \\
\text { Filled } \\
\text { Grains/ } \\
\text { Panicle }\end{array}$ & $\begin{array}{c}\text { Total } \\
\text { No. of } \\
\text { Grains/ } \\
\text { Panicle }\end{array}$ & $\begin{array}{c}\text { Fertility } \\
\%\end{array}$ & $\begin{array}{l}\text { Solid } \\
\text { Loss }\end{array}$ & $\begin{array}{l}\text { Water } \\
\text { Uptake }\end{array}$ & $\begin{array}{c}\text { Volume } \\
\text { Expansi } \\
\text { on Ratio }\end{array}$ & $\begin{array}{c}\text { Alkali } \\
\text { Spreading } \\
\text { Value }\end{array}$ & $\begin{array}{l}\text { Leng } \\
\text { th/Br } \\
\text { eadth } \\
\text { Ratio }\end{array}$ & $\begin{array}{c}\text { Amylose } \\
\text { Content } \\
(\%)\end{array}$ \\
\hline Cluster I & 112.67 & 25.84 & 109.19 & 15.27 & 37.90 & 18.06 & 244.33 & 268.09 & 91.09 & 1.48 & 73.27 & 2.28 & 3.61 & 2.84 & 22.73 \\
\hline Cluster II & 101.38 & 28.51 & 112.85 & 13.92 & 45.68 & 19.60 & 292.50 & 315.58 & 92.19 & 1.54 & 53.50 & 2.17 & 3.35 & 2.78 & 21.87 \\
\hline Cluster III & 104.22 & 29.38 & 112.29 & 14.44 & 41.10 & 16.16 & 333.89 & 356.67 & 93.39 & 2.25 & 65.00 & 2.12 & 3.44 & 3.10 & 22.27 \\
\hline Cluster IV & 102.50 & 27.61 & 118.47 & 14.33 & 43.75 & 17.90 & 247.83 & 277.67 & 89.88 & 1.35 & 56.50 & 1.82 & 3.08 & 2.78 & 21.44 \\
\hline Cluster V & 98.33 & 25.19 & 101.93 & 15.67 & 36.13 & 22.79 & 312.33 & 362.67 & 86.41 & 0.80 & 52.00 & 2.00 & 2.00 & 2.26 & 24.24 \\
\hline Cluster VI & 103.33 & 24.92 & 116.07 & 14.67 & 39.10 & 18.83 & 279.33 & 306.67 & 90.99 & 0.60 & 111.67 & 3.00 & 4.00 & 3.51 & 22.17 \\
\hline
\end{tabular}

Bold figures are indicated maximum and minimum mean values for each character

\begin{tabular}{|c|c|c|c|c|c|c|c|c|c|c|c|}
\hline $\begin{array}{l}\text { Character/ } \\
\text { cluster No. }\end{array}$ & $\begin{array}{c}\text { Protein } \\
\text { Content } \\
(\%)\end{array}$ & $\begin{array}{c}\text { Total } \\
\text { Starch } \\
\text { Content }(\%)\end{array}$ & $\begin{array}{c}\text { Total Phenol } \\
\text { Content(mg/100g) }\end{array}$ & $\begin{array}{c}\text { Total } \\
\text { Antioxidant } \\
\text { Activity(mg } \\
\text { AAE/100g) }\end{array}$ & $\begin{array}{c}\text { Flavanoid } \\
\text { Content } \\
(\mathrm{mg} / \mathbf{1 0 0 g})\end{array}$ & $\begin{array}{c}\text { Zn } \\
\text { Content }\end{array}$ & $\begin{array}{c}\text { Fe } \\
\text { Content }\end{array}$ & $\begin{array}{l}\text { Glycemic } \\
\text { Index }\end{array}$ & $\begin{array}{c}\text { Slowly } \\
\text { Digestible } \\
\text { Starch }\end{array}$ & $\begin{array}{c}\text { Rapidly } \\
\text { Digestible } \\
\text { Starch }\end{array}$ & $\begin{array}{c}\text { Resistant } \\
\text { Starch }\end{array}$ \\
\hline Cluster I & 8.89 & 68.90 & 65.29 & 59.72 & 172.74 & 18.13 & 9.69 & 57.55 & 37.73 & 59.83 & 2.44 \\
\hline Cluster II & 11.66 & 76.65 & 96.49 & 88.43 & 430.73 & 25.27 & 10.69 & 61.01 & 35.04 & 62.88 & 2.30 \\
\hline Cluster III & 13.24 & 59.19 & 160.54 & 89.22 & 580.13 & 24.83 & 12.80 & 60.39 & 36.12 & 59.03 & 2.67 \\
\hline Cluster IV & 12.80 & 69.96 & 128.07 & 99.05 & 554.09 & 19.40 & 10.95 & 62.49 & 32.88 & 62.79 & 1.83 \\
\hline Cluster V & 8.21 & 87.57 & 56.36 & 105.13 & 303.80 & 25.90 & 10.70 & 57.12 & 39.40 & 58.48 & 2.12 \\
\hline Cluster VI & 10.95 & 66.13 & 214.34 & 108.83 & 590.12 & 24.30 & 13.40 & 69.25 & 30.89 & 67.55 & 1.56 \\
\hline
\end{tabular}

Bold figures are indicated maximum and minimum mean values for each character 
Table.6 Contribution of different characters towards genetic divergence among 26 genotypes of colored rice (Oryza sativa L.)

\begin{tabular}{|c|c|}
\hline Character & Percent contribution towards divergence \\
\hline Days to $50 \%$ flowering & 0.01 \\
\hline Panicle length $(\mathrm{cm})$ & 0.01 \\
\hline Plant height (cm) & 0.01 \\
\hline Ear bearing tillers per plant & 0.01 \\
\hline Grain Yield per plant (g) & 0.01 \\
\hline Test Weight (g) & 0.01 \\
\hline Number of filled grains per panicle & 0.01 \\
\hline Total number of grains per panicle & 0.01 \\
\hline Fertility $\%$ & 0.01 \\
\hline Solid Loss & 0.01 \\
\hline Water Uptake & 1.85 \\
\hline Volume Expansion Ratio & 0.01 \\
\hline Alkali Spreading Value & 0.01 \\
\hline Length/Breadth ratio & 0.01 \\
\hline Amylose Content (\%) & 0.01 \\
\hline Protein Content (\%) & 0.01 \\
\hline Total Starch Content (\%) & 0.31 \\
\hline Total Phenol Content (mg/100g) & 0.62 \\
\hline Total antioxidant Activity (mg AAE/100g) & 0.31 \\
\hline Flavonoid content (mg/100g) & 4.00 \\
\hline Zn content (ppm) & 1.54 \\
\hline Iron content (ppm) & 0.01 \\
\hline Glycemic Index & 0.31 \\
\hline Slowly Digestible Starch (\%) & 18.15 \\
\hline Rapidly Digestible Starch (\%) & 1.54 \\
\hline Resistant Starch (\%) & 71.38 \\
\hline
\end{tabular}

Maximum grain yield was recorded in cluster II and the genotypes in cluster VI had high mean values for most of the bio-chemical quality parameters. Cluster II recorded maximum intra cluster distance while highest inter cluster distance was observed between cluster V and cluster VI.

Hence, it may be concluded that hybridization among genotypes from cluster $\mathrm{V}$ and VI, cluster I and VI followed by cluster II and VI with high inter cluster distances may result in maximum genetic improvement and the segregants possessing high grain yield coupled with desirable physico-chemical and biochemical quality parameters may be isolated in future segregating generations.

Results of the present study indicated maximum inter cluster distance between cluster V \& VI and high intra cluster distance in cluster II \& III hence, the genotypes from these clusters may be identified for hybridization programme to incorporate high grain yield and superior quality characters in the segregating generations. 


\section{Conflicts of Interest}

The authors Sri Devi, P., Krishna Veni, B and Sandeep Raja, D declare that they have no conflicts of interest.

\section{References}

Allard, R.W. 1960. Principles of Plant Breeding. John Wiley and Sons Inc., New York. 485.

Directorate of Rice Research (DRR, Hyderabad). 2006. Laboratory Manual on Rice Grain Quality Procedures.

Dushyantha, K.B.M. 2008. Genetic divergence in red Rice (Oryza sativa L). Karnataka Journal of Agricultural Sciences. 21 (3): 346-348.

Englyst, K.N., Englyst, H.N., Hudson, G.J., Cole, T.J., and Cummings, J.H. 1999. Rapidly available glucose in foods: An in-vitro measurement that reflects the glycemic response. American Journal of Clinical Nutrition. 69: 448-454.

Eswar, R.R., Veni, B.K., Kumar, P.V.R and Rao, V.S. 2017. Morphological and molecular diversity in rice (Oryza sativa L.). Journal of Rice Research. 10 (2): 1-6.

Goni, I., Diz, L.G., Manas, E and Calixto, F.S. 1996. Analysis of resistant starch: a method for foods and food products. Food Chemistry. 56 (4): 445-449.

Goni, I., Alonso, A.G and Calixto, F.S. 1997. A starch hydrolysis procedure to estimate glycemic index. Nutrition Research. 17 (3): 427-437.

Hodge, J.E and Hofrieter, B.T. 1962. In: Methods in carbohydrate chemistry, Academic press, New York.

Juliano, B.O. 1971. A simplified assay for milled rice amylose. Cereal Science Today. 16: 334-338.

Little, R.R., Hilder, G.B., Dawson, E.H and Elsie, H. 1958. Differential effect of dilute alkali on 25 varieties of milled white rice. Cereal Chemistry. 35: 111126.

Lowry, O.H., Rosebrough, N.G., Farr, A.L and Randall, R.J. 1951. Journal of Biological Chemistry. 193, 265.

Mahalanobis, P.C. 1936. On the generalized distance in statistics. Proccedings of National Institute of Science. (India), 12: 49-55.

Malik, C.P and Singh, M.B. 1980. In: Plant Enzymology and Histo Enzymology, kalyani publishers, New Delhi.

Odenigbo, A.M., Michael, N., Ejebe, C., Nwankpa, C., Danbaba, N., Sali, N and John, M. 2013. Study on the gelatinization properties and amylose content of rice varieties from Nigeria and Cameroun. International Journal of Nutrition and Food Sciences. 2 (4): 181-186.

Parimalan, R., Joel, A. J. and Vanniarajan, C. 2008. Genotypes clustering in rice (Oryza sativa L.). Crop Improvement. 35(2): 115-118.

Patindol, J.A., Guraya, H.S., Champagne, E.T and Anna, M.M. 2010. Nutritionally important starch fractions of rice cultivars grown in southern united states. Journal of Food Science. 75 (5): 137-144.

Pathirana, C.M.L and Shahidi, F. 2005. Antioxidant properties of commercial soft and hard winter wheats (Triticum aestivum L.) and their milling fractions. Journal of the Science of Food and Agriculture. 86: 477-485.

Ramesh, C.P., Singh, S.S.K., Bose, L.K and Singh, O.N (2007). Multivariate Analysis in Upland Rice Genotypes. World Journal of Agricultural Sciences 3(3): 295-300.

Sandhya, K.N., Babu, V.R., Ansari, N.A and Ravichandran, 2007. Genetic divergence analysis using yield and quality traits in rice (Oryza sativa L.). Crop improvement 34 (1): 12-15. 
Sidhu, J.S., Gill, M.S and Bains, G.S. 1975. Milling of paddy in relation to yield and quality of rice of different Indian varieties. Journal of Agriculture and Food Chemistry. 23: 1183-1185.

Swain, T and Hills, W.E. 1959. The phenolic constituents of Prunus domestica. The quantitative Analysis of phenolic constituent. Journal of the Science of Food and Agriculture. 10 (1): 63-68.

Yawadio, R., Tanimori, S and Morita, N. 2007. Identification of phenolic compounds isolated from pigmented rice and their aldose reductase inhibitory activities. Food Chemistry 101: 1616-1625.

\section{How to cite this article:}

Sri Devi, P., B. Krishna Veni and Sandeep Raja, D. 2019. Genetic Diversity for Yield Components, Physical and Biochemical Quality Parameters in Colored Rice (Oryza sativa L.). Int.J.Curr.Microbiol.App.Sci. 8(11): 18-26. doi: https://doi.org/10.20546/ijcmas.2019.811.003 